\title{
Welfare Racism: \\ Playing the Race Card Against America's Poor
}

Kenneth J. Neubeck and Noel A. Cazenave

New York: Routledge, 2001.

\section{Reviewed by Krista Johnson}

In their book: Welfare Racism: Playing the Race Card Against America's Poor, Kenneth J. Neubeck and Noel A. Cazenave chart the evolution of welfare racism in the United States through a detailed analysis of specific case studies. Beginning with the 1911 mother's pensions (largely intended for white widowed women), Neubeck and Cazenave demonstrate that U.S. welfare policy has been racialized, gendered and stigmatized from its very inception, at times excluding and discriminating against African Americans, ${ }^{1}$ and at other times providing a limited form of highly stigmatized assistance. Using their concept of welfare racism as an analytical tool, the authors explain that: 
... welfare racism exists as a major force shaping contemporary public assistance attitudes, policies and practices ... it serves three major social stratification and social control functions for racialized societies and their "racial states." Welfare racism provides: (1) social prestige for the general white population, (2) political and career power for its politicians and other elites, and (3) economic acquisition for the nation's economic elite in the form of a large and easily exploitable low-wage labor pool (12).

In tracing the ways that welfare racism exists, persists and changes (12), Neubeck and Cazenave reveal the mythical and erroneous and persistent characterization of African-American women as "welfare queens" or "welfare mothers." Through detailed case studies and thorough analysis, the authors trace the historical evolution of such stereotypes as welfare provision evolved from mother's pensions to Aid to Dependent Children (ADC), later known as Aid to Families with Dependent Children (AFDC). The authors also explain that such stigmatization occurred despite the fact that early ADC provided assistance to many more poor white families and at greater levels of compensation. In addition, they cite recent evidence that "African Americans and whites have been about equally represented on the welfare rolls for many years" (4).

The history of racialized and stigmatized nature of welfare policy is evident in current welfare provisions, allocated in the U.S. through the Temporary Assistance for Needy Families (TANF) provision of the Personal Responsibility and Work Opportunity Reconciliation Act (PRWORA), which President Clinton used to replace the AFDC in 1991. Such punitive welfare reforms rely on welfare racism to legitimize large cuts to social provisions and encourage public support for "ending welfare as we know it." ${ }^{2}$ This discourse is particularly targeted at African-American women, and draws on stereotypes of the "welfare queen" or "welfare mother." As Neubeck and Cazenave explain, "[t]he unusually harsh and punitive character of the 'welfare reform' policies that have been proposed or implemented in the wake of such debates has often reflected a preoccupation with controlling the alleged sexual immorality and supposed preference for welfare over work of one group: African-American females" (4).

Indeed, the authors draw extensively on expanding literature about gender and racism in welfare and social policy. Recent works by Francis Fox Piven, Mimi Ambrovitz, Gwendolyn Mink, Gail Lewis, and Sanford Schram have explored the racist and sexist foundations of welfare policy, primarily in the U.S. and Britain. ${ }^{3}$ Wel fare Racism: Playing the Race Card Against America's Poor j oins this body of work, and provides an excellent framework and model for such analyses.

In addition, Neubeck and Cazenave articulate their criticism of some recent works, which in their opinion don't go far enough in exposing the racist foundations of American social policy ( such as Gilens's Why Americans Hate Welfare). The 
authors note that much of this literature falls into three categories: "perspectives that emphasize the importance of class, gender, or state-centered forces in shaping welfare policy" (13). Although they acknowledge the importance of such analyses, Neubeck and Cazenave employ a very different framework. They write: "[w]e, in contrast, offer a racism-centered perspective for understanding U.S. welfare policy. Our framework draws attention to the racialized nature of U.S. society as a whole and the existence of a racial state that has long served as the political instrument of societywide white racial hegemony" (13). This racism-centered framework provides an excellent lens for exploring the links between stigmatized welfare policy and stereotypes of poor racialized women and men in U. S. social and political discourse. Using this framework, the authors are able to reveal that such stereotypes have served the political and economic purposes of the ruling elite. As a challenge to contemporary discourses on welfare and the hegemonic power structures that continue to stigmatize those seeking assistance, Cazenave and Neubeck are beginning to challenge the racist underpinnings of past and contemporary U.S. welfare policy.

There is, however, one major shortcoming in their analysis. Although they provide an excellent overall integration of gender into their analysis of welfare policy, Neubeck and Cazenave's work falls short in their limited analysis of stereotypes and constructions of the African-American family. As the family is the site where discussions of women's lives and social status are most often operationalized, this would provide an excellent ground for a further extension of their analysis. The prevalence of discourses of children and family in the political rhetoric surrounding U.S. welfare policy is striking-Aid for Dependent Children (ADC), Aid for Families with Dependent Children (AFDC) and Temporary Assistance for Needy Families (TANF) all demonstrate this in name as well as in their emphasis on the provision of a "suitable home" despite conditions of abject poverty. This condition is closely tied to speculations about the immorality of African-American women and their inability to provide such a "suitable home," without acknowledging the effects of racism in perpetuating poverty and unemployment (see Chapter 7).

In their study of ADC provisions in Washington D.C. during the 1960s, Neubeck and Cazenave explain that:

The District's ADC eligibility rules ... (e.g., such as the District's employable parents and "man-in-the-house" rules) actually worked against family stability.... One of these rules denied aid to children in situations where "the mother associates with a man in a relationship similar to that of husband and wife, and the mother, her children and the man live in a family setting regardless of whether the man is the father of the children." The second rule forbade aid to children when the "mother maintains a 
'husband-wife relationship' and the man continues a relationship with the children similar to that of father and child, even though the man claims to be living at an address different from the mother's address." In short, these two ADC rules outlawed any type of "husband-wife relationship," be it with a man inside or outside of the home. (101)

These kinds of "man-in-the-house" eligibility rules have remained an implicit part of welfare policy in the U.S. ${ }^{4}$ Although Neubeck and Cazenave stress the negative impact such rules had on family formation and partnering in AfricanAmerican households, they fail to recognize the implicitly sexist and heterosexist aspects of such rules. Essentially, such policies attempt to structure families and partnering relationships in very specific ways, subject to the control and approval of the state. Firstly, there is an assumption that the "man-in-the-house" will be in a position to financially support the family, regardless of the degree of involvement between adults, or that he will be in the household "freeloading"off of the meagre provisions intended for the children. ${ }^{5}$ Despite the fact that women are discouraged from engaging in relationships that may provide parenting assistance, such rules unfairly stigmatize single female-headed households. Neubeck and Cazenave fail to acknowledge that the 'man-in-the-house' rule also denies women the right to chose who may enter their lives and under what pretenses, granting the majority of such control to the state. The nuclear family model is held up as the "normal" family arrangement (an example of the "suitable home"or "suitable family"), thus invoking stereotypes of the African-American family as delinquent and unhealthy, and denying the African-American woman the same level of autonomy and personal choice as other women in the U.S. In addition, the perpetuation of such stereotypes paves the way for the state to intervene in race population control through family caps and other more explicit control of certain women's reproductive rights.

Related to this issue, Neubeck and Cazenave also fail to mention contemporary movements that emphasize marriage as the only way to promote "healthy" twoparent families. Indeed, in March 2000 some states began to encourage "welfare mothers" to marry by providing specific funds for the purposes of marriage. Dr. Wade F. Horn, currently of the U.S. Health and Human Services Department, was relentless in lobbying for the enactment of welfare reform legislation promoting marriage. In April of 2000 he wrote that:

Theoretically, states could have devoted 100 percent of their welfare block-grant funds to this purpose. More realistically, they were expected to devote at least some portion of these funds to promote marriage. In actuality, states devoted nothing - not one red cent. Until March 21, [2000] that is. In a bold move, Governor Keating of Oklahoma announced on that date that he would be using $\$ 10$ million in federal welfare block- 
grant funds to encourage healthy, stable marriages as a means of reducing divorce, out-of-wedlock childbearing, and welfare dependency. [my emphasis] (1)

The primary goal of such policies is to perpetuate the stigmatized image of African-American families as deviant, as well as to reinforce the hegemonic racialized gender order. Not only do such policies write-out non-heterosexual family arrangements, they also reinforce the assumption that a household without a (state-sanctioned and approved) husband or father is abnormal and unhealthy. This is further demonstrated in Horn's suggestion that:

Marriage is indispensable to the well-being of a healthy society... That's because research consistently finds that communities with high marriage rates have fewer social pathologies, including less crime and less welfare dependency, than communities with low marriage rates [italics mine] .6

Thus, the man-in-the-house rule and the emphasis on healthy marriages as markers of healthy families further reinforce welfare racism and strengthen the control of the state over women's reproductive and individual rights, while denying certain women the right to chose who shares their lives and on what grounds. In addition, such policies structure the families and personal relationships of women receiving TANF ( and previously ADC and AFDC) in specific ways, suggesting that they must ascribe to the normative (but not predominant) model of the nuclear, two-headed, heterosexual family, which is not expected of the average American citizen.

Despite this shortcoming in their analysis, Neubeck and Cazenave provide a useful framework for the analysis welfare racism in numerous contexts. This text also overlaps and intersects nicely with other work being done on the racialized nature of the nation-state, immigration policy, and regimes of inequality. In particular, this framework could be used to reveal the institutionalized nature of racism, sexism, and homophobia entrenched within various social policies.

The authors also provide convincing evidence of the potential for change and improvement to social policy. The final chapter of Welfare Racism delineates contemporary movements toward challenging and exposing the racism of welfare in U.S. policy. In addition, the authors express their firm belief that changes to social policy will also provide an avenue for long-term and sustainable social and political change.

As Neubeck and Cazenave explain:

Reforms to existing welfare reform measures alone cannot take us where we need to go in terms of the elimination of poverty and racism and the 
reduction of gender and class inequalities... "Lines, begun parallel and left alone, can never touch." The actual elimination of racism-in all of its many forms and manifestations-requires nothing less than a radical transformation of U.S. society and what is not its racial state. While this task is, indeed, a daunting one, the prize is even greater, and the journey has already begun. (242)

Welfare Racism sets us even further ahead on this path.

1. The authors focus on the racialization of African Americans is due to the lack of research and information on racialization of other targeted populations, and also due to the fact that negative images of Black women and men are central to many of the discourses around welfare policy.

2. This was Bill Clinton's 1992 campaign promise, which he realized with the 1996 PRWORA. See page 4.

3. See "References" for full citations.

4. Currently, these rules are known as "spouse-in-the-house." In Ontario, these are manifested in the ODSP (Ontario Disability Support Program) and dictate that claimants will no longer be eligible for TANF provisions if they co-habitate with a partner whose combined income exceeds a certain figure (see the DAWN web site). Of course, similar legislation exists in other Canadian and American programs.

5. There is also an unspoken yet implicitly racist notion that the partners of AfricanAmerican women receiving ADC will also be African-American, assuming that interracial relationships will not occur in such contexts, but that poor African-American women will "stick to their kind."

6. Dr. Horn does not provide supporting documentation or citations for these claims.

\section{References}

Ambrovitz, M. (1996). Regulating the lives of women: Social welfare policy from colonial times to the present. Boston: South End Press.

Fox Piven, F. and Cloward, R. (1993 ). Regulating the poor: The functions of public welfare. New

York: Vintage Books.

Horn, Wade F. (2000, April 6). Use welfare money to promote marriage. Jewish World Review Online: http://www.dadi.org/wh promo.htm

Lewis, G. (Ed.). (1998). Forming Nation, Framing Welfare. New York: Routledge. Mink, G. (1998). Welfare's end. Ithaca, NY: Cornell University Press.

Neubeck, K. J. and Cazenave, N. A. (2001). Welfare racism: Playing the race card against America's poor. New York: Routledge. 
Quadagno, J. (1994). The color of welfare: How racism undermined the war on poverty. New

York: Oxford University Press

Schram, S. F. (2000). After welfare: The culture of postindustrial social policy. New York: New York University Press. 